\title{
OPISY ZWIERZĄT NA PRZYKŁADZIE LWA W BESTIARIUSZU PHILIPPE'A DE THAON
}

\begin{abstract}
Streszczenie. Philippe de Thaon był klerykiem piszącym w pierwszej ćwierci XII w. Pozostawił po sobie teksty o tematyce przyrodniczej, wśród których wyróżnić należy pierwszy francuskojęzyczny bestiariusz. Pierwszym opisanym w nim zwierzęciem jest lew. Źródło to - Livre des Bestaires - zostało zestawione z wcześniejszymi tekstami, na które autor się powoływał - Fizjologami w różnych redakcjach (grecka, łacińska, Bis - uzupełniony fragmentami Izydora z Sewilli) oraz Etymologiae Izydora z Sewilli. Źródła te powstały między II, a VII w. stanowiły w średniowieczu podstawę wiedzy o przyrodzie. W każdym z nich lew jest pierwszym opisanym zwierzęciem. Źródła te z reguły prezentują pozy tywny obraz króla zwierząt. Zawierają też wspólne opisy, jak np. sen z otwartymi oczami. Jednocześnie autorzy każdego kolejnego źródła dopisywali nowe elementy do już istniejącego opisu, przy czym Philippe de Thaon zapisał najbardziej szczegółową charakterystykę lwa. W sferze symbolicznej również zauważyć można zmiany, mimo zachowania podobnego trzonu tradycji przedstawieniowej. Ewolucja ta przebiega podobnie, jak przy opisie fizycznym. Wyjątkiem jest tu Etymologiae, w którym wyjaśnienia symboliczne nie zostały podane przez autora.
\end{abstract}

Słowa kluczowe: bestiariusz, lew, Philippe de Thaon, średniowiecze, literatura średniowieczna, przyroda, Livre des bestiaires.

$\mathrm{P}$

rzyroda od zawsze fascynowała człowieka. Świadczą o tym najstarsze ślady działalności ludzkiej - amulety z zębów i rogów, malowidła naskalne, najstarsze mity. Obok jej postrzegania przez pryzmat wyłącznie religijny zaczęto także podejmować próby jej naukowego opisywania, co widać choćby w pismach Arystotelesa. Na poły fantastyczne, na poły rzeczywiste, pisma przyrodnicze szczególną popularność zyskały w średniowieczu jako tzw. bestiariusze, czyli opisy zwierząt. 
Warto przyjrzeć się im bliżej na przykładzie najstarszego tekstu tego typu w języku wernakularnym, autorstwa Philippe'a de Thaon. Dla zawężenia zakresu tematycznego, niniejsza praca nie będzie szczegółową analizą całości tekstu, a jedynie opisu lwa wraz z pokazaniem przemian jakim podlegała, czyli tego, czy i w jakim stopniu jego opis zmieniał się w różnych źródłach. Zdecydowano się na omówienie tego zwierzęcia nie tylko ze względu na jego królewską symbolikę, ale również dlatego, że od jego opisu zazwyczaj zaczynają się bestiariusze. Dodatkowo istotne wydaje się postawienie pytania, dlaczego w przeciwieństwie do wcześniejszych źródeł autor napisał Livre des Bestiaires w języku francuskim, a nie łacińskim. Z tych powodów jego przedstawienie $\mathrm{w}$ bestiariuszu Thaona (cytowanego wg. edycji Walberga z 1900 r.) zostanie skonfrontowane z innymi, istotnymi dla średniowiecza tekstami - Fizjologiem (zarówno w redakcjach greckich, jak i łacińskich) oraz Etymologiae Izydora z Sewilli ${ }^{1}$.

Na samym początku omówione zostaną źródła, które stanowią podstawę analizy, czyli greckie i łacińskie redakcje Fizjologa, następnie dzieło Izydora z Sewilli oraz Livre des Bestiaires Thaona. Następnie zostaną omówione i streszczone te fragmenty wybranych źródeł, które bezpośrednio dotyczą tematu wraz ze wskazaniem podobieństw i różnic w nich występujących.

Opisy zwierząt często zawierają znaczenia symboliczne, które są im przypisywane. Stąd też w pracy funkcjonują zamiennie określenia „symbol” i „alegoria”, które, choć obecnie są wyraźnie rozróżniane, to w średniowieczu traktowane były synonimicznie.

\section{Fizjolog}

Jednym z najważniejszych wczesnochrześcijańskich źródeł dotyczących postrzegania przyrody jest Fizjolog. Został on napisany między II, a IV w. n.e. najprawdopodobniej w Aleksandrii, jednak nie jest to pewne ${ }^{2}$. Zdaniem Jacquesa le Goffa mógł powstać kręgu gnostyckim, który pełny był symbolizmu, a który, jest wymieniany w spisie ksiąg z VI w. jako tekst heretycki ${ }^{3}$.

${ }^{1}$ Fizjolog, tłum. K. Jażdżewska, Warszawa 2003 [dalej: Fizjolog]; Fizjologi i Aviarium. Średniowieczne traktaty o symbolice zwierzq̨t, tłum. S. Kobielus, Kraków 2005 [dalej: Fizjolog łac.]; Izydor z Sewilli, Etymologiarum Libri XX, Patrologiae Latinae, t. 82, acc. J.P. Migne, Parisiis 1850; Le Bestiaire De Philippe De Thaûn. Texte Critique Publié Avec Introduction, Notes Et Glossaire, par. E. Walberg, Lund 1900; S.H. Cottin-Bizonne, Une nouvelle édition du Bestiaire de Philippe de Thaon [rozprawa doktorska], Chapel Hill 2003, http://b-ok.xyz/book/2767323/ 2d51a9, dostęp: 15.09.2018.

2 Fizjolog, s. 10.

${ }^{3}$ J. le Goff, Niezwykli bohaterowie i cudowne budowle średniowiecza, Warszawa 2011, s. 63; S. Kobielus, Bestiarium chrześcijańskie. Zwierzęta w symbolice i interpretacji. Starożytność i średniowiecze, Warszawa 2002, s. 27. 
Fizjolog jest kompilacją źródeł greckich, rzymskich, a także Biblii. Do naszych czasów nie zachował się żaden rękopis pierwotny lub najstarsze łacińskie redakcje, trzeba jednak pamiętać, że jako źródło funkcjonujące w tradycji ustnej mogło istnieć ich wiele różniących się między sobą. Jego treść jest dobrze znana z późniejszych odpisów ${ }^{4}$. Składa się zazwyczaj z 48 lub 49 rozdziałów poświęconych zwierzętom lądowym, ptakom i kamieniom. Opisy poszczególnych stworzeń wzbogacone zostały o cytaty z Pisma Świętego. Utwór ma charakter moralitetu, przy każdym opisie autor zawarł przykłady z Biblii mające na celu uwiarygodnienie wyjaśnienia moralnego. Zarówno zwyczaje zwierząt, jak również ich symbolika mogą się znacząco różnić między sobą w poszczególnych redakcjach, np. w redakcji pseudo-bazyliańskiej (przypisywana św. Bazylemu datowana na X-XII) jednorożec bądź lew są powiązane z diabłem 5 .

Jego najstarszy rękopis łaciński pochodzi z IX w. (wcześniej datowany był na przełom VII i VIII) ${ }^{6}$. Wersja łacińska zdaniem badaczy jest poszerzona względem redakcji w języku greckim ${ }^{7}$. Współcześni badacze podzielili zachowane rękopisy na 4 grupy, z których najważniejsza dla tekstu Philippe'a jest wersja BIs ${ }^{8}$, powstała między VIII a IX w. Charakteryzuje się ona tekstem uzupełnionym o fragmenty Ethymologiae Izydora z Sewilli, o którym będzie mowa niżej. Stanisław Kobielus uważa, iż Fizjolog stał się $w$ średniowieczu podręcznikiem chrześcijańsko-symbolicznej zoologii ${ }^{9}$.

\section{Etymologiae}

Autorem tego źródła był Izydor z Sewilli (560-636). Człowiek ten, ogłoszony Doktorem Kościoła (1722) był osobą świetnie wykształconą - znał łacinę, grekę, według niektórych badaczy także hebrajski ${ }^{10}$. Jego najważniejszym dziełem jest Etymologiae znana także jako De Origines. Składa się ono z piętnastu-dwudziestu ksiąg (podział ten pochodzi od wydawców), które omawiają różne sfery funkcjonowania świata - m.in. aniołów, retorykę, budownictwo ${ }^{11}$. Pisząc swoje dzieło, korzystał z prac wielu autorów

${ }^{4}$ I. Dines, The problem of the Transitional family of bestiaries, „Reinardus. Yearbook of the International Reynard Society" 2011-2012, 24, s. 2931.

${ }^{5}$ Fizjolog, s. 10-11, 77-78.

${ }^{6}$ F.J. Carmody, De Bestiis et aliis rebus and the latin Physiologus, „Speculum” 1938, vol. 13/2, s. 153.

${ }^{7}$ Ibidem, s. 154.

${ }^{8}$ Pisownię tę stosuję za: Fizjolog łac, s. 33 i nast.

${ }^{9}$ S. Kobielus, Bestiarium..., s. 29.

${ }^{10}$ H. Dressel, De Isidore Originum Fontibus, Augustae Taurinorum 1874, s. 10; The Etymologies of Isidore of Seville, red. S.A. Barney, W.J. lewis, J.A. Beach, O.Berghof, Cambridge 2006, s. 7.

11 Ibidem, s. 8. 
antycznych, m.in. Pliniusza czy Korneliusza Celsusa, choć zazwyczaj nie wspomina ich z imienia ${ }^{12}$. Z perspektywy omawianego zagadnienia istotna jest księga XII nosząca tytuł De Animalibus. Izydor, podobnie jak Arystoteles i Pliniusz, opisał w niej różne zwierzęta żyjące na świecie, ich zwyczaje oraz pochodzenie nazw. Skracał przy tym opisy antycznych autorów ${ }^{13}$. W dziele tym nie widać wpływów Fizjologa w tym sensie, iż nie opisuje on symboliki stworzeń ${ }^{14}$.

\section{Livre des Bestiaires}

Philippe przyszedł na świat pod koniec XI w., prawdopodobnie w Thaon, małej wsi niedaleko Caen. Jego wujem był Hunfei de Thaon, seneszal i kapelan królewski ${ }^{15}$. Wspomniał go w swoim dziele Cumpoz. Działalność literacka Thaona jest datowana przez Shannon Hogan Cottin-Bizonne między 1113 a $1154 \mathrm{r}^{16}$

Jego teksty to $\mathrm{w}$ większości przekłady na dialekt anglonormandzki utworów łacińskich ${ }^{17}$. Z całą pewnością nie są to jednak przekłady sensu scricto. Pisząc swoje prace opierał się na wielu źródłach, o czym wspomina we wstępach swych prac, w tym w bestiariuszu.

Cumpoz napisany został między 1113 a 1119 r. Świadczy o tym dedykacja dla wuja, który, jak wynika z tekstu, musiał wtedy jeszcze żyć. Datacja ta wskazuje też, że jest to najwcześniejsze dzieło Thaona ${ }^{18}$. Max Friedrich Mann wskazał ponadto, że pewne fragmenty zostały, jako szablon, wykorzystane w Livre des Bestiaires ${ }^{19}$.

Przypisuje mu się też autorstwo Livre de Sybile, utworu napisanego ok. 1130-1135 (według Cottin-Bizonne tekst ten należy datować na lata 40. XII w.), na co wskazuje podobieństwo stylu z bestiariuszem i Computem ${ }^{20}$.

12 Ibidem, s. 11-14. Heinrich Dressel dużo miejsca poświęca też cytowaniu Salustiusza przez Izydora; ibidem, passim.

${ }^{13}$ Przykład takiego postępowania: Ibidem, s. 41.

${ }^{14}$ Isidore of Seville, op. cit., s. 424-472; C.S. Lewis, Odrzucony obraz. Wprowadzenie do literatury średniowiecznej i renesansowej, Kraków 1995, s. 149.

15 Ch.V. Langlois, La connaissance de la nature et dumondu au Moyen Age. D'apres quelques écrits français a l'usage des laics, Paris 1911, s. 2.

${ }^{16}$ S.H. Cottin-Bizonne, op. cit., s. 1.

17 Ch.V. Langlois, op. cit., s. 1.

18 A. Krappe, The Historical Background of Philippe de Thaün'sBestiaire, „Modern Language Notes" 1944, vol. 59, s. 325.

19 M.F. Mann, Der Physiologus des Philipp von Than und seine Quellen, ein Beitrag zur allgemeinen Geschichte der Literatur des Mittelalters, Halle 1884, s. 8, 39-40.

${ }^{20}$ S.H. Cottin-Bizonne, op. cit., s. 3; H. Shields, Philippe de Thaon, auteur du Livre de Sibylle, „Romania” 1964, t. 85, no. 340, s. 466 i nast. 
Zachowały się trzy rękopisy Livre des Bestiaires, które obecne znajdują się w Londynie, Oksfordzie oraz Kopenhadze. Są one niekompletne, najstarszy z nich to londyński, zawierający jednocześnie najpełniejszą treść. Manuskrypty z Oksfordu i Kopenhagi są opatrzone w ilustracje. W londyńskim one nie występują, choć z treści źródła wynika, że miały być zamieszczone w rękopisie ${ }^{21}$.

Data powstania tego źródła nie jest całkiem pewna. Piszący na początku XX w. Charles-Victor Langlois twierdził, że bestiariusz powstał między 1121 a 1135 r. (są do daty trwania małżeństwa Henryka I i Adeli) 22. Sylvia Huot twierdzi, że nastąpiło to ok. $1125^{23}$. Można zatem przyjąć, że w przybliżeniu tekst powstał w latach 20. XII w.

Bestiariusz ten ma dwie adresatki. Początkowo pisany był dla Adeli, żony króla Anglii Henryka I Beauclerca ${ }^{24}$, jednak jeden z rękopisów - oksfordzki - wskazuje tu Eleonorę, dziedziczkę księstwa Akwitanii, i żonę Henryka II ${ }^{25}$. Dedykacja tego tekstu królowej, jak wskazuje Alexander Krappe, miała na celu wypromowanie autora ${ }^{26}$.

Livre... napisana została sześciozgłoskowcem (miejscami siedmiozgłoskowcem), który w części trzeciej - dotyczącej kamieni- zamieniony został na ośmiozgłoskowiec (od wersu 2890). Wersy są połączone rymami w układzie aabb.

\section{Opis lwa - źródła}

W najstarszej, greckiej redakcji Fizjologa lew został opisany jako król dzikich zwierząt. Posiada on trzy wyjątkowe cechy - potrafi zacierać swoje ślady ogonem, gdy wyczuje myśliwych, a kiedy śpi to z otwartymi oczami. Samiec lwa po trzech dniach oddechem przywraca życie swym młodym, te bowiem według tego źródła rodzą się martwe ${ }^{27}$.

${ }^{21}$ X. Muratova, The decorated manuscripts of the bestiary of Philippe de Thaon (the Ms. 3466 from the Royal Library in Copenhagen and the Ms. 249 in the Merton College Library, Oxford) and the problem of the illustrations of the medieval poetical bestiary, [w:] Third International Beast Epic, Fable and Fabliau Colloquium, Münster 1979: proceedings, red. J. Goossens, T. Sodmann, Köln 1981, s. 231.

${ }^{22}$ Ch.V. Langlois, op. cit., s. 3. Datację tę przytacza też L.H. Lops; idem, Le pélican dans le bestiaire de Philippe de Thaun, „Neophilologus: An International Journal of Modern and Mediaeval Language and Literature" 1995, t. 79, s. 377.

${ }^{23}$ S. Huot, Bestiary, [w:] Medieval France. An encyclopedia, red. W.W. Kibler, G.A. Zinn, L. Earp, London-New York 1995, s. 225.

${ }^{24}$ Ch.V. Langlois, op. cit., s. 2.

${ }^{25}$ Ibidem, s. 5.

${ }^{26}$ A. Krappe, op. cit., s. 325-326.

${ }^{27}$ Fizjolog, s. 23-24. 
Zacieranie śladów zostało przez greckiego autora porównane do Chrystusa, który ukrywał swą boskość. Czuwanie podczas snu to obecność Boga przy Jezusie podczas krzyżowania ciała, zaś trzy dni to nawiązanie do zmartwychwstania ${ }^{28}$.

Odmienny obraz lwa znaleźć można w redakcji pseudo-bazyliańskiej. Podobnie jak w redakcji greckiej mowa jest w nim o trzech właściwościach Treść zachowanego fragmentu informuje o zacieraniu śladów oraz spaniu $\mathrm{z}$ otwartymi oczami, jednak robi z odmiennych przyczyn. Zostawia pozorne ślady, dzięki którym zdobywa pożywienie, by nieświadome zagrożenia zwierzęta znalazły się w pobliżu rzeczywistego legowiska lwa, stając się dla niego pożywieniem. Śpi zaś z otwartymi oczami, by widzieć ofiary. Zostało to zinterpretowane jako zachowanie diabła, który pokusami stara się przyciągnąć do siebie człowieka ${ }^{29}$.

Fizjolog w redakcji łacińskojęzycznej posiada opis zawarty w dwóch akapitach. Incipit pierwszego głosi: Rozpoczynamy od opisu lwa, króla zwierzq̨t $i$ dzikich bestii ${ }^{30}$. Źródło to opisuje najpierw zacieranie śladów, by myśliwy nie mógł go odnaleźć. To zachowanie posiada dwa wyjaśnienia symboliczne. Pierwsze odwołuje się do ukrywania boskości Chrystusa, drugie zaś do ukrywania dobrych uczynków, by szatan nie doprowadził człowieka do grzechu. Druga cecha to wskrzeszanie młodych po trzech dniach do ich narodzin. Zostało to porównane z Jezusem, który zmartwychwstał po trzech dniach, dzięki czemu poganie (w języku źródła non credebant) odzyskali duchowe życie ${ }^{31}$.

Fizjolog BIs podobnie jak redakcja grecka zawiera informacje o trzech naturach lwa. Zaciera on swoje ślady, gdy wyczuje myśliwych, co zostało zinterpretowane jako ukrywanie boskiej natury przez Chrystusa. Spanie $\mathrm{z}$ otwartymi oczami jest alegorią czuwania Boga, gdy jego ziemskie ciało umarło. Wskrzeszanie młodych po trzech dniach od narodzin (podobne jak w redakcji greckiej rodzą się martwe) to obraz zmartwychwstania ${ }^{32}$.

Lew otwiera także podrozdział De Bestiis będący fragmentem księgi XII De etymologiae noszącej tytuł De animalibus. Nazwa tego zwierzęcia pochodzi z greki i oznacza króla. Lew, jak twierdzi Izydor, jest władcq wszystkich dzikich zwierzq̨ $t^{33}$. Autor wyróżnia, ze względu na wygląd, 3 rodzaje lwów - mające grzywę kędzierzawą są niewielkie i spokojne, z wydłużonym

\footnotetext{
${ }^{28}$ Ibidem.

${ }^{29}$ Ibidem, s. 77.

${ }^{30}$ De Leone ferarum atque animalium rege dicere incipimus. Fizjolog, [w:] Fizjolog łac., s. 17.

${ }^{31}$ Ibidem, s. 17-18.

${ }^{32}$ Dominus meus obdormiens in cruce et sepultus, deitas eius vigilabat; Fizjolog Bis, [w:] Fizjolog łac., s. 37.

33 „Princeps sit omnium bestiarum”; Izydor z Sewilli, op. cit., XII, II, 3-6, s. 433-434.
} 
ciałem oraz prostą grzywą. Wyrażają swe emocje głową i ogonem, męstwo kryją w piersi, ich siła również znajduje się w głowie. Boją się odgłosu kół, ognia oraz białego koguta. Potrafią być miłosierne, zjadają ludzi tylko, gdy są głodne, ciężko też je zdenerwować. Podobnie jak w Fizjologu również w tym źródle znaleźć można informacje o zacieraniu śladów ogonem oraz o tym, że młode rodzą się martwe, a po trzech dniach samiec wskrzesza je swym rykiem ${ }^{34}$.

Podobnie jak Fizjologi i De Bestiis, również bestiariusz Philippe’a de Thaon rozpoczyna się od przedstawienia lwa, któremu autor poświęcił aż 367 wersów swojego dzieła. Jego opis zaczyna się od wyjaśnienia greckiej nazwy, która oznacza króla. Ma on przerażający wygląd, kwadratową klatkę piersiową, wielką grzywę i długi, zadbany ogon. Chodzi na równych nogach, jego pazury są długie i zakrzywione. Kiedy jest głodny może zjeść każde zwierzę ${ }^{35}$. Kiedy chce jeść kopie dziurę w ziemi i zostawia ją otwartą i żadne zwierzę prócz tych, które wyznaczy nie przekroczy tego znaku. Autor kończy ten fragment opisu jego zachowania informacją o rysunku, który ma to obrazować ${ }^{36}$. Kiedy jest zły, przytrzymuje swymi łapami zwierzę na ziemi, co również zostało zilustrowane ${ }^{37}$. W sytuacji, w której gonią go myśliwi, zaciera swoje ślady ogonem, aby nie mogli go znaleźćc ${ }^{38}$. Lew ma w zwyczaju spać $\mathrm{z}$ otwartymi oczami i boi się piania białego koguta ${ }^{39}$. Ma on też w zwyczaju drżeć, gdy widzi człowieka ${ }^{40}$. Ostatnim zachowaniem lwa, o którym wspomina Thaon, jest przywracanie życia potomstwu po trzech dniach rykiem ${ }^{41}$. Podobny, choć względem bestiariusza znacznie krótszy opis tego zwierzęcia zawarł on w Li Cumpoz, w części dotyczącej znaków zodiaku i ich alegorii ${ }^{42}$.

W Livre des Bestiaires lew jest symbolem Jezusa, który rządzi wszystkimi ludźmi. Jest potężniejszy od wszystkich zwierząt. Jednocześnie autor zaznacza, że Chrystus nie jest królem Żydów, gdyż Ci go ukrzyżowali, stąd te przyjdzie ich osądzić. Kwadratowa pierś jest obrazem siły boskości, a tył natury ludzkiej, którą łączył z boskością. Ogon jest obrazem roztaczanej wokół sprawiedliwości. Łapy zakończone pazurami symbolizują Boga, który trzyma

34 Ibidem.

35 Le Bestiaire De Philippe De Thaûn, w. 25-46.

36 Ibidem, w. 93-108.

37 Ibidem, w. 121-126.

38 Ibidem, w. 157-164.

39 Ibidem, w. 223-228.

40 Ibidem, w. 347-352.

41 Ibidem, w. 363-370. Użyte w tekście słowo crie może też oznaczać płacz, jednak, biorąc pod uwagę źródła wcześniejsze, najpewniej chodzi o ryk: http://www.anglo-norman.net/ gate/index.shtml?session=SNWK31764T1487500525, dostęp: 15.09.2018.

42 Li Cumpoz Philipe de Thaün. Der Computus des Philipp von Thaun mit einer Einleitung über der Sprache des Autors, red. E. Mall, Strassburg 1873, s. 56-57. 
świat, zaś same szpony - zemstę na Żydach. Oni też są symbolizowani przez zad lwa. Autor tłumaczy to tym, że będąc głupimi z natury, odwrócili się od Boga, a ich zbawienie możliwe jest tylko dzięki Bożemu Miłosierdziu ${ }^{43}$. Ogon ma dwa znaczenia: jest jednocześnie obrazem Pisma Świętego i Bożej sprawiedliwości. Wykopana przez lwa dziura jest obrazem Raju, do którego mogą wejść ludzie (tu autor używa zwrotu w 1. os. l. mn.), jeśli będą postępować dobrze i wyrzekną się zła ${ }^{44}$. Wściekłość lwa jest alegorią Chrystusa (tym razem wskazanego z imienia), który musi karać ludzi postępujących przeciw $n^{n i e m u}{ }^{45}$. Zacieraniu śladów ogonem autor powiązał z wcieleniem. Bóg przybrał ludzkie ciało, aby zbawić ludzkość, jednak gdyby diabeł się dowiedział o inkarnacji nie doszłoby do zbawienia przez krzyż. Aniołowie też o tym nie wiedzieli, dlatego Bóg przybył w swym majestacie i dopiero po wcieleniu zażądał ich obecności. Miał mieć wtedy na sobie czerwony płaszcz, jako symbol odkupienia ludzkości przez męczeńską śmierć ${ }^{46}$. Biały kogut, powiązany z lwem jest alegorią świętego męża, czyli Chrystusa, co zostało przez autora potwierdzone cytatem z Pisma o zaparciu się Piotra w Wielki Piątek. Z tej alegorii Philippe wyciągnął naukę o śpiewaniu godzin kanonicznych - jeśli nie są śpiewane pozwala się na działanie diabłom. Sen z otwartymi oczami jest symbolem zmartwychwstania, gdyż dzięki śmierci pokonał szatana (zobrazowanego tu przez śmierć) ${ }^{47}$. Drżenie na widok człowieka jest symbolem pokory, kiedy boskość zastąpił człowieczeństwem na ziemi ${ }^{48}$. Lwica płacząca nad młodymi jest obrazem Maryi. Lew-Chrystus spędził trzy dni w grobie, a jego ryk symbolizuje moc Boga, w tym kontekście - opróżnienie piekła i zmartwychwstanie ${ }^{49}$.

\section{Opis lwa - interpretacja}

0 pozytywnej symbolice lwa wypowiadał się już Arystoteles. Zwierzę to wiązał z ucieleśnieniem męskości. Politeistyczne kulty starożytne wiążą go m.in. ze słońcem albo, jak u Sasanidów, ze strażnikami Drzewa Życia. Już starożytni Egipcjanie i Sumerowie łączyli go z królewskością ${ }^{50}$. Częściowo podobny obraz wyłania się w Biblii. Staje się on tam obrazem męstwa, sprawiedliwości, królewskości. Był też, tak jak widać to w Fizjologu oraz licznym

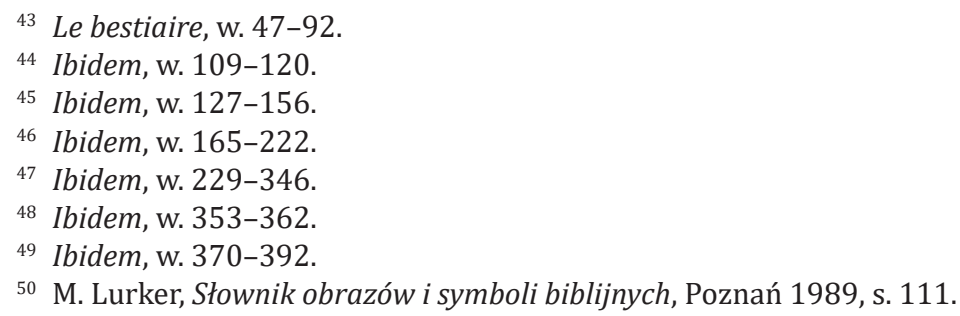

50 M. Lurker, Słownik obrazów i symboli biblijnych, Poznań 1989, s. 111. 
zachowanych bestiariuszach symbolem Chrystusa ${ }^{51}$. Nie należy przy tym zapominać, że lew posiadał też konotacje negatywne. Przykłady takiej interpretacji znajdują się również w Piśmie Świętym, chociażby w Psalmie 21, albo w liście Św. Piotra: Przeciwnik wasz, diabeł, jak lew ryczący krąży szukając kogo pożrećs ${ }^{2}$. Z tego powodu w średniowieczu lew miał zarówno konotacje pozytywne, jak i negatywne. Widać to również w sztuce, w której od poł. XI w. zaczął pojawiać się coraz częściej ${ }^{53}$. Spotkać go można w literaturze pięknej, na monetach, pieczęciach, m.in. jako symbol władzy ${ }^{54}$. Z drugiej strony rzeźby popularne w Prusach rzeźby w stylu „Madonn na lwach” przedstawiają to zwierzę jako pokonanego diabła. XIII-wieczna mappa mundi z Hereford wpisuje się $\mathrm{w}$ ten problem. Zwierzę to jest tam prawie niemożliwe do odróżnienia od lamparta ${ }^{55}$. Ostatecznie w bestiariuszach zwyciężył obraz pozytywny. Negatywne cechy tego zwierzęcia przejął inny ssak z rodziny kotowatych - wspomniany wyżej lampart ${ }^{56}$. Opis lwa rozpoczyna niemal wszystkie bestiariusze. Historyk rzymski Plutarch nie wspominał o zacieraniu śladów ogonem, ale pisał o tym, że lwy śpią z otwartymi oczami ${ }^{57}$. Informacje te zostały później przejęte przez autorów bestiariuszy.

Warto zatem zobaczyć, jak zmieniał się opis lwa w streszczonych wyżej źródłach. Znaczenie nazwy pojawia się w niemal wszystkich źródłach, podobnie jak jej powiązane z greckim słowem oznaczającym króla, choć w przypadku Thaona prawdopodobnie zostało to zaczerpnięte bezpośrednio z Fizjologa BIs. Jest to też jedyne źródło mówiące wprost o ilustracjach. Wygląd fizyczny został omówiony w Ethymologiae (za nim powtarza Fizjo$\log B I s$ ) oraz u Thaona, przy czym ten ostatni podał najwięcej szczegółów dotyczących jego wyglądu. W przypadku zwyczajów można wskazać więcej podobieństw. Prawie wszystkie źródła wspominają o trzech głównych zachowaniach, przy czym, ze względu na uszkodzenie tekstu, redakcja pseudo-bazyliańska omawia tylko zacieranie śladów i sen z otwartymi oczami. Wyjątkiem jest tutaj redakcja łacińska, która podaje tylko dwie cechy - ukrywanie drogi i wskrzeszanie młodych. Zauważyć też można pojawianie się elementów nowych. Izydor opisując lwa pisze o jego miłosierdziu i strachu

51 S. Kobielus, Bestiarium chrześcijańskie..., s. 180-182; D. Forstner, Świat symboliki chrześcijańskiej, Warszawa 1990, s. 275-280.

$521 \mathrm{P}, 5,8$.

53 M. Pastoureau, Średniowieczna gra symboli, Warszawa 2006, s. 59.

54 T. Panfil, Lingua symbolica. O pochodzeniu i znaczeniu najstarszych symboli heraldycznych w Polsce, Lublin 2002, s. 96-128.

55 A. Collins, Symbolism of animals and birds represented in English church architecture, New York 1913, s. 70.

${ }^{56}$ M. Pastoureau, op. cit., s. 64.

57 F. McCulloch, Medieval Latin and French bestiaries, Chapel Hill 1962, s. 137. 
przed białym kogutem. Philippe, powielając te informacje, dodaje, że młode są wskrzeszane rykiem oraz kopaniem dziury w ziemi. Warto zwrócić na to uwagę, gdyż oprócz tego źródła tylko redakcja pseudo-bazyliańska informuje o kopaniu. Wynika z tego, że Thaon musiał korzystać także z innych źródeł niż te, o których wspomina.

Symbolika lwa również ulegała przemianom. Niemal wszystkie źródła łączą go z Chrystusem. Zacieranie śladów, które pojawia się w niemal wszystkich opisach, było symbolem boskości schowanej w ludzkim ciele, większe odstępstwo widać w łacińskiej redakcji Fizjologa, gdzie oprócz sensu chrystologicznego jest również interpretacja ludzka. Wyraźniejsze zmiany zaobserwować można przy wyjaśnieniach wskrzeszania młodych, gdzie oprócz zmartwychwstania opisany został się $w$ redakcji łacińskiej motyw przywracania pogan do życia w Bogu. Philippe de Thaon powtarza główne wyjaśnienia symboliczne zawarte w źródłach wcześniejszych, dopisując własne w budowie fizycznej lwa, drżeniu na widok koguta czy też powiązaniu koguta z Wielkim Piątkiem. Redakcja pseudo-bazyliańska jest wyjątkiem, który nie znajduje kontynuacji w omawianych źródłach. Izydor z Sewilli zaś konsekwentnie pomija opisy symboliczne zwierząt w swych Etymologiach.

\section{Wnioski}

Lew był zwierzęciem, któremu w średniowieczu przypisywane rozmaite cechy. Mimo że trzon opisu fizycznego i interpretacji we wszystkich źródłach jest podobny, to poszczególni autorzy dodawali coś nowego. Widać to chociażby na przykładzie redakcji łacińskiej i BIs, które, choć mają tę samą genezę, wykazują między sobą różnice. $\mathrm{Z}$ wyjątkiem redakcji pseudo-bazyliańskiej wszystkie źródła prezentują pozytywny obraz lwa, przy czym najbardziej rozbudowany znajduje się w Livre des Bestiaires. Zawiera ona nie tylko dokładny opis wyglądu, ale też najszczegółowiej omówioną symbolikę. W jej treści widać nie tylko dobrą znajomość źródeł wcześniejszych, ale jest też w niej, prawdopodobnie, ślad tego, że autor widział to zwierzę żywe ${ }^{58}$. Poprzez wybór języka francuskiego tekst Philippe de Thaon był bardziej zrozumiały dla odbiorców, czyli dworu królewskiego. Taki wybór odbiorców, wraz z rodzącą się kulturą rycerską (w podobnym czasie została spisana, również w Anglii, najstarsza znana wersja Chanson de Roland) „wymuszał” powstanie tekstu, który prócz wskazania królowi, jak należy postępować dawał też innym członkom dworu możliwość lepszego zrozumienia otaczającego ich świata. Występowanie zwierząt $\mathrm{z}$ bestiariusza w heraldyce, bądź

${ }^{58}$ A. Krappe, op. cit., s. 326. 
przedmiotach codziennego użytku (np. akwamanile), których początki są zbliżone czasowo do spisana Livre... wskazują na potrzebę elit, by móc bez znajomości łaciny poznać znaczenie pojawiających się w nich istot.

\section{BIBLIOGRAFIA}

\section{Źródła}

Cottin-Bizonne Shannon Hogan, Une nouvelle édition du Bestiaire de Philippe de Thaon [rozprawa doktorska], Chapel Hill 2003, http://b-ok.xyz/book/2767323/2d51a9, dostęp: 15.09.2018.

The Etymologies of Isidore of Seville, red. S.A. Barney, W.J. Lewis, J.A. Beach, O. Berghof, Cambridge 2006.

Fizjolog, przeł. K. Jażdżewska, Warszawa 2003.

Fizjologi i Aviarium. Średniowieczne traktaty o symbolice zwierząt, tłum. S. Kobielus, Kraków 2005.

Izydor z Sewilli, Etymologiarum Libri XX, Patrologiae Latinae, t. 82, acc. J.P. Migne, Parisiis 1850.

Le Bestiaire De Philippe De Thaûn. Texte Critique Publié Avec Introduction, Notes Et Glossaire, par. E. Walberg, Lund 1900.

Li Cumpoz Philipe de Thaün. Der Computus des Philipp von Thaün mit einer Einleitung über der Sprache des Autors, red. E. Mall, Strassburg 1873.

Philippe de Thaon, Livre des bestiaries, Det kongelige Bibliotek, Kopenhagen, MS. GKS $34668^{\circ}$, http://www.kb.dk/permalink/2006/manus/225/eng//?var, dostęp: 15.09.2018.

Philippe de Thaon, Livre des bestiaries, Merton College MS. 249, http://image.ox.ac.uk/show-allopenings? collection=merton\&manuscript=ms249, dostęp: 15.09.2018.

Popular Treatises On Science Written During The Middle Ages, In Anglo-Saxon, Anglo-Norman, And English, red. T. Wright, London 1841.

\section{Opracowania}

Anglo-Norman Dictionary, http://www.anglo-norman.net/, dostęp: 15.09.2018.

Carmody F.J., De Bestiis et aliis rebus and the Latin Physiologus, „Speculum” 1938, vol. 13/2, s. 153-159.

Collins A., Symbolism of animals and birds represented in English church architecture, New York 1913.

Dines I., The problem of the Transitional family of bestiaries, „Reinardus. Yearbook of the International Reynard Society" 2011-2012, 24, s. 29-52.

Dressel H., De Isidore Originum Fontibus, Augustae Taurinorum 1874.

Forstner D., Świat symboliki chrześcijańskiej, Warszawa 1990. 
Kobielus S., Bestiarium chrześcijańskie. Zwierzęta w symbolice i interpretacji. Starożytność i średniowiecze, Warszawa 2002.

Krappe A.H., The Historical Background of Philippe de Thaün's Bestiaire, „Modern Language Notes" 1944, vol. 59, s. 325-327.

Langlois Ch.-V., La connaissance de la nature et du mondu au Moyen Age. D’apres quelques écrits français a l'usage des laics, Paris 1911.

Le Goff J., Niezwykli bohaterowie i cudowne budowle średniowiecza, Warszawa 2011.

Lewis C.S., Odrzucony obraz. Wprowadzenie do literatury średniowiecznej i renesansowej, Kraków 1995.

Lops R.L.H., Le pélican dans le bestiaire de Philippe de Thaun, „Neophilologus: An International Journal of Modern and Mediaeval Language and Literature” 1995, t. 79, s. 377-387.

Lurker M., Słownik obrazów i symboli biblijnych, Poznań 1989.

Mann M.F., Der Physiologus des Philipp von Thaün und seine Quellen, ein Beitrag zur allgemeinen Geschichte der Literatur des Mittelalters, Halle 1884.

McCulloch F., Medieval Latin and French bestiaries, Chapel Hill 1962.

The Medieval Bestiary, http://bestiary.ca/index.html, dostęp: 15.09.2018.

Medieval France. An encyclopedia, red. W.W. Kibler, G.A. Zinn, L. Earp, London-New York 1995.

Panfil T., Lingua symbolica. O pochodzeniu i znaczeniu najstarszych symboli heraldycznych $w$ Polsce, Lublin 2002.

Pastoureau M., Średniowieczna gra symboli, Warszawa 2006.

Third International Beast Epic, Fable and Fabliau Colloquium, Münster proceedings, red. J. Goossens, T. Sodmann, Köln 1981.

Łukasz Makowski

\title{
DESCRIPTIONS OF ANIMALS ON EXAMPLE OF LION IN PHILIPPE DE THAON'S BESTIARY
}

\begin{abstract}
D hilippe de Thaon was a clerc, who worked in first quarter of XII century. He had left texts about nature science, in which must be distinguish $1^{\text {st }}$ French-language bestiary. This source - Livre des bastiaires - was compared with earlier texts, which were sources of information for author - Physiologus in various version (greek, latin, BIs- supplemented by part of Isidore of Seville's Etymologiae) and Etymologiae of Isidore of Seville. These sources was popular in Middle Ages, and all had been written in beginning centuries of Christianity. Lion is first animal in all of these sources. Sources, generally, presenting positive image of king of animal. They containing also the same describing, like, f. ex. sleeping with an opening eyes. Simultaneously authors of every later sources added a new elements to behavior or look, wherein Philippe de Thaon made the most detailed description. In symbolical aspects also it is looked a changes, althought preserving simile tradition of describing. Evolution of that aspect was similar like in physical description. Etymologiae in an unusual source, because author had not written symbolical explanation of animals.
\end{abstract}

Keywords: bestiary, Philippe de Thaon, middle ages, medieval literature, nature, Livre des Bestiaires. 